\title{
JOB SATISFACTION OF IT PROFESSIONALS IN POLAND: DOES BUSINESS COMPETENCE MATTER?
}

\author{
Jolanta KOWAL ${ }^{1}$, Narcyz ROZTOCKI ${ }^{2}$ \\ ${ }^{1}$ The Department of Historical and Pedagogical Sciences, The Institute of Psychology, \\ University of Wroctaw, Dawida 1 Street, 50-527 Wroctaw, Poland \\ ${ }^{2}$ School of Business State, University of New York at New Paltz, 1 Hawk Drive, New Paltz, NY \\ 12561-2443, USA, \\ Kozminski University, 57/59 Jagiellońska Street, 03-301 Warsaw, Poland \\ E-mails: ${ }^{1}$ jolakowal@gmail.com; ${ }^{2}$ roztockn@newpaltz.edu (correspondingauthor)
}

Received 24 June 2013; accepted 13 May 2014

\begin{abstract}
This paper examines the effects of business competence on the job satisfaction of Information Technology (IT) professionals in Poland. The necessary data is collected from a survey conducted among 391 IT professionals working in various companies in Poland. The results of the analysis indicate that business competence, in general, positively affects the job satisfaction of IT professionals in transition economies. However, business competence seems to have mixed effects on various aspects of job satisfaction. Although business competence affects satisfaction with co-workers, supervision and work itself, the surveyed IT professionals feel that business competence does not have any substantial effect on their salary level and professional promotions. The theoretical implication of this study is that systematic development of human capital by building business competence will have positive effects on the job satisfaction of IT professionals in transition economies. This paper also has a practical implication for managers in transition economies seeking improvements in productivity as it may help them to devise a compensation and promotion system that would better account for competency in their employees.
\end{abstract}

Keywords: Business competence, business knowledge, human capital, information technology management, IT professionals, job competency, job satisfaction, Poland, transition economies.

JEL Classification: J00, J30, J31, J32, J40, M50.

\section{Introduction}

Although many information technology (IT) investments are conducted in transition economies like Central and Eastern Europe, limited research about exactly which job competency assures stable employment and professional carrier combined with job satisfaction is reported from this region (Roztocki, Weistroffer 2015). The majority of studies on job satisfaction was conducted in Western Europe and North America (Eyupoglu, Saner 2009), while not much is known about job satisfaction in countries in Central and Eastern Europe (Lange 2009). Despite more than two decades of 
transition process, there is a substantial economic gap between transition economies and the mature, developed economies (Kowal, Roztocki 2013). One explanation of the persistence of this economic gap could be seen in the so-called "fragile human capital" (Soja, Paliwoda-Pekosz 2013). In essence, many companies in transition economies struggle with the development of human capital resources, since many employees leave the countries to seek positions in mature, developed economies that would give them better salaries and promotion prospects, thus making hiring and retaining competent employees an issue (Kowal, Roztocki 2015; Piotrowicz 2015). However, competent and better trained employees with the prospect of higher salary and promotion are more likely to innovate, which in turn leads to a strengthening of the company's position in the global market (Díaz-Fernández et al. 2014; Vila et al. 2014). Thus, understanding the relationship between competency and job satisfaction can indirectly serve to improve the economic situation in many transition economies.

In the context of this paper, we define job competency as a set of abilities and attitudes "that might directly or indirectly affect job performance" (Woodruffe 1993). Job satisfaction can be defined as an affective or attitudinal reaction to a job (Spector 1985). Several aspects, such as pay, promotion, co-workers, supervisors, and work itself, may constitute the overall satisfaction with the job (Vitell, Davis 1990).

In this research, we attempt to close the gap by investigating the relationship between business competency and job satisfaction in Poland, a transition economy located in Central and Eastern Europe. Thus, the main research question guiding our research is formulated as follows: Does business competency lead to job satisfaction among IT professionals working in companies in Central and Eastern Europe? The rest of the paper is structured as follows. In the proceeding section, we review literature related to business environment in transition economies, business competency, and job satisfaction. The results of literature review are then used in establishing a set of hypotheses. These hypotheses are tested using data from a structured survey conducted among IT professionals working for companies in Poland. Next, the results of this survey are presented and implications are discussed. After outlying our contribution, we conclude the paper with presenting some ideas for future research.

\section{Background and literature review}

\subsection{Business environment and the IT use in transition economies}

Transition economies are economies that are in a long-term process of transition from a centrally planned economic system to a market driven system (Roztocki, Weistroffer 2011a). Although the transformation started more than two decades ago, many transition economies still suffer from the communist past in the form of a lingering government bureaucracy and managerial attitudes not fully attuned to free market economy (Roztocki, Weistroffer 2009). In addition, often unclear legislation present in many transition economies, also a relic of the past times of a centrally planned economy (Soja 2008), complicates business operations.

Existing reports point to differences in management style. For example, managers in transition economies in general seem to rely less on hard data in comparison to their 
colleagues in developed, mature economies. This may be explained in absence of historical data and need for managerial flexibility in fast changing regulatory environment (Kozminski 2008). Moreover, as compared to the developed countries, in transition economies many managers identify themselves less with their company and often tend to look at the firm only with their own interest in mind (Soja 2008). This could be another relic within the history of a centrally planned economy as one the main objectives of the companies was to provide work and income for populace (Roztocki, Weistroffer 2008).

\subsection{Job competency of IT professionals}

Relatively few reports related to the competency of employees in transition economies exist. In one study Parts et al. (2013) conducted a survey among 534 alumni of the Tallinn University of Technology one and half years after their graduation. Most respondents were employed and satisfied with their job. They felt that both technical competences (computer and learning skills, professional knowledge) and non-technical competences (social competences, self-expression and presentation skills, and foreign language) are necessary for employability.

Therefore, in addition to a solid technical knowledge, also called IT competency (Bassellier et al. 2001), successful IT professionals must pose a robust understanding of business and have effective interpersonal skills (Todd et al. 1995). Overall this set of nontechnical skills, also termed as business competence, accordingly to the taxonomy proposed by Bassellier and Benbasat (2004), and could be divided in two categories: organization specific and interpersonal and management. This taxonomy of business competence is summarized in Table 1.

Table 1. Business competency categories of IT professionals (Adapted from Bassellier and Benbasat (2004))

\begin{tabular}{|c|c|c|}
\hline $\begin{array}{l}\text { Competency } \\
\text { category }\end{array}$ & Sub-category & Description \\
\hline \multirow[t]{4}{*}{$\begin{array}{l}\text { Organization } \\
\text { specific }\end{array}$} & $\begin{array}{l}\text { Organizational } \\
\text { overview }\end{array}$ & $\begin{array}{l}\text { Knowledge about the organization, its goals, core } \\
\text { capabilities, customers, and competitors. }\end{array}$ \\
\hline & $\begin{array}{l}\text { Organizational } \\
\text { units }\end{array}$ & $\begin{array}{l}\text { Understanding functions of various organizational units } \\
\text { and their role in achieving goals of the organization. }\end{array}$ \\
\hline & $\begin{array}{l}\text { Organizational } \\
\text { responsibility }\end{array}$ & $\begin{array}{l}\text { Responsibility of IT professionals for organizational } \\
\text { business processes and their outcomes. }\end{array}$ \\
\hline & $\begin{array}{l}\text { IT-business } \\
\text { integration }\end{array}$ & $\begin{array}{l}\text { Ability to use IT as problem solver for various } \\
\text { organizational business problems. }\end{array}$ \\
\hline \multirow{3}{*}{$\begin{array}{l}\text { Interpersonal } \\
\text { and } \\
\text { management }\end{array}$} & $\begin{array}{l}\text { Knowledge } \\
\text { networking }\end{array}$ & $\begin{array}{l}\text { Knowing where knowledge resides within and outside } \\
\text { the organization. }\end{array}$ \\
\hline & $\begin{array}{l}\text { Interpersonal } \\
\text { communication }\end{array}$ & $\begin{array}{l}\text { Ability to develop and maintain relationships with others, } \\
\text { capability to develop a social network across various } \\
\text { organizational units and beyond boundaries } \\
\text { of organization. }\end{array}$ \\
\hline & Leadership & $\begin{array}{l}\text { Skills to manage and ability to find ways of integrating } \\
\text { business processes with IT. }\end{array}$ \\
\hline
\end{tabular}




\subsection{Job satisfaction}

Job satisfaction is frequently defined as the emotional-affective response of the employees to the job (Spector 1985). Job satisfaction is an important organizational construct as it could explain employee motivation, their performance, absenteeism and turn-over (Koh, Boo 2001). Motivated employees positively affect firm performance. Multiple aspects, such as pay, security, initiative, opportunities for independent decision-making, responsibility, sense of achievement, hours of work, promotion prospects, working with pleasant people and pressure at work (Lange 2009), may explain the satisfaction with a given job.

Regarding job satisfaction in transition economies, Linz (2003) studied satisfaction among Russian workers and identified factors affecting the level of job satisfaction. In general, Russian workers were satisfied with their job, and there were positive correlations between job satisfaction and organizational commitment. No differences in job satisfaction were reported between genders; however, older employees are more likely to be satisfied than younger ones. S. M. Carraher and S. C. Carraher (2006) examined the applicability of traditional human resources management theories to 375 owners of small- to medium-sized enterprises in Belarus, Poland and Ukraine. Performance and annual incomes were relatively unrelated to job satisfaction. Regarding the relationships between performance, income, and job satisfaction, the authors think that many assumptions that are based on the traditional Western human resource management do not operate well with business owners in transition economies of Eastern Europe.

In a comparative study, Fargher et al. (2008) compared the impact of cultural values and beliefs on job satisfaction in eight transition economies with job satisfaction of twelve developed countries in Western Europe. Contrary to the developed economies, in transition economies the importance of family/friends and religion as a predictor for job satisfaction is not substantial. Sakowski (2012) studied job satisfaction of occupational medicine nurses in Poland. He observed low satisfaction with salary and promotion opportunities. He reports that about 26 percent of nurses who participated in the survey considered leaving Poland to find a job in one of mature, developed economies.

In a different study, Ubius et al. (2013) compared job satisfaction in three transition economies in Eastern Europe (Czech Republic, Estonia and Slovakia) with two counties in Asia (Japan and China). In contrast to the Asian counties where the innovation climate in an organization positively affects job satisfaction in transition economies, the relationship between innovation climate in a company and the level of job satisfaction was not identified in this study.

\section{Research hypotheses}

We decided to use the environmental hypothesis as the theoretical foundation of our study (Roztocki, Weistroffer 2011b). In transition economies, there are many environmental factors that are typical for many of these economies and may potentially affect the job satisfaction of IT professionals. The transition from a centrally planned to a market 
economy, created opportunities for independent decision-making at the firm level, which resulted in more flexible reward mechanisms and larger income inequalities (Lange 2009). Overall, many transition economies are faced with typical conditions prevalent in emerging economies where there is a high demand for highly qualified workers but salaries remain low as compared with developed economies (Roztocki, Weistroffer 2011b). The relatively low salaries may motivate IT professionals working in transition economies to seek new job opportunities in and outside the country.

On first look, in a job market characterized by high demand for IT professionals and high employee turnover, employees possessing more than only technical skills may better brand themselves while looking for new employment opportunities. In addition, possessing solid business competence may help IT professionals advance in their company. Overall, strong business capabilities should support IT professionals' advancement in their job, which will subsequently lead to greater job satisfaction.

In order to provide an answer to the main research question, we decided to use a set of three hypotheses. In essence, these three hypotheses state that business competence does not have any effect on job satisfaction of IT professional working in transition economies. Obviously, we expect that these three hypotheses would be accepted.

Thus, we propose the following hypothesis to test whether or not business competence of IT professionals working in companies in Central and Eastern Europe has an effect on their job satisfaction:

H1: Business competence of IT professionals has significant effect on their job satisfaction.

Moreover, we were also interested in knowing if there is a difference in how organization-specific business knowledge and interpersonal and management knowledge affect job satisfaction.

Understanding the connection between IT and the business of an organization is an important non-technical skill and is referred to as organization-specific business knowledge (Bassellier, Benbasat 2004). This knowledge allows understanding the business of the company, its strategies and sources of competitive advantage. It is about organizational goals and objectives, core capabilities, and the business environment in which the company operates. It is also related to understanding the top management's preferences, as well as companies' policies and culture. It is quite reasonable to expect that the organization-specific business knowledge will affect employees' choices and their job satisfaction. However, it takes time to accumulate the organization-specific business knowledge, and this kind of business competency is not easy transferable.

Therefore, regarding organizational specific business knowledge, we propose the following hypothesis to test whether or not this business competence of IT professionals working in companies in Central and Eastern Europe has an impact on their job satisfaction:

H2: Organization specific business knowledge of IT professionals has significant effect on their job satisfaction. 
Interpersonal and management knowledge is the ability to interact with and manage others (Bassellier, Benbasat 2004). It includes personal skills, such as the ability to build a professional network, interpersonal communication skills, and leadership skills (Bassellier, Benbasat 2004). Interpersonal and management knowledge may have a large impact on job satisfaction, as it is transferable to different organizations, and IT professionals with these skills are more likely to be promoted.

Thus, in regard to interpersonal and management knowledge, we propose the following hypothesis to test whether or not this business competence of IT professionals working in companies in Central and Eastern Europe has an effect on their job satisfaction:

H3: Interpersonal and management knowledge of IT professionals has significant effect on their job satisfaction.

Our research model is depicted in Figure 1.

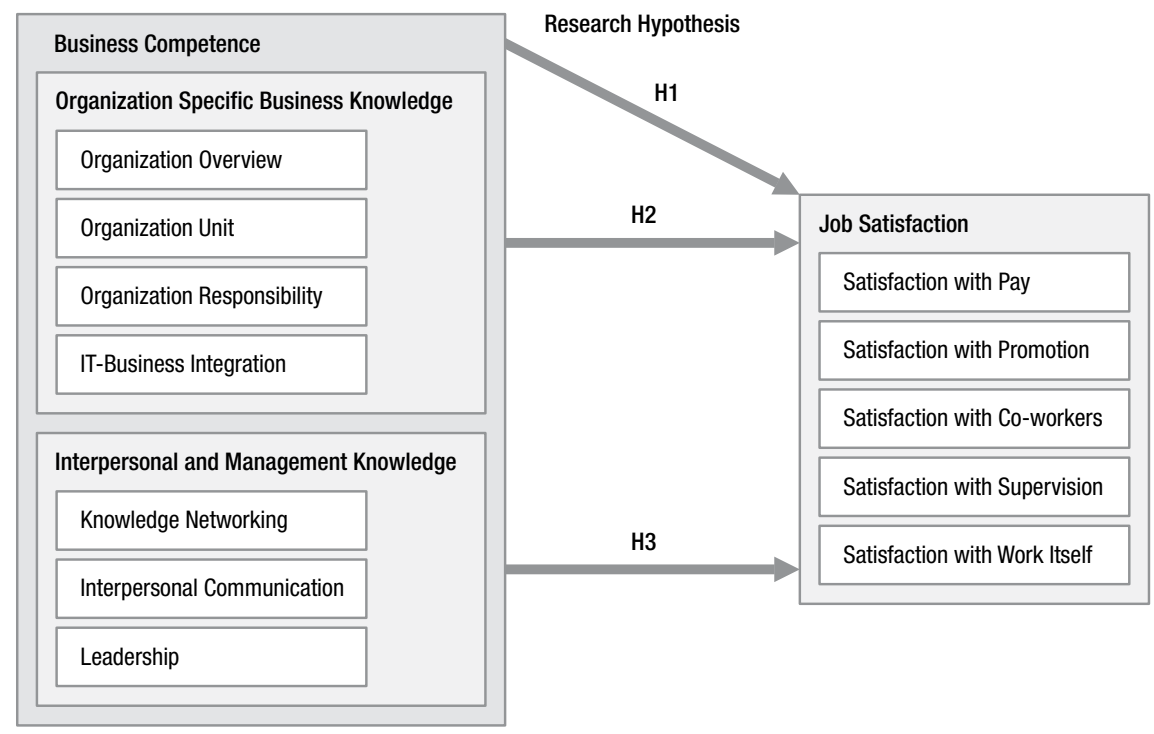

Fig. 1. Research framework

\section{Methodology}

To test the research hypothesis that guided our research, we decided to use a survey. This survey was conducted among IT professionals working for companies that are located in in Poland.

\subsection{Research questionnaire development}

To measure the independent variables related to business competence, we adopted the questionnaire developed by Bassellier and Benbasat (2004). The questions are depicted in Tables 2 and 3. 
Table 2. Items for business competence regarding organization specific knowledge

(Adapted from Bassellier and Benbasat (2004))

\begin{tabular}{|c|c|c|}
\hline Dimension & $\begin{array}{l}\text { Variable } \\
\text { name }\end{array}$ & Question \\
\hline \multirow[t]{4}{*}{$\begin{array}{l}\text { Organizational } \\
\text { overview }\end{array}$} & OVR1 & $\begin{array}{l}\text { Rate your level of knowledge of the organization's external } \\
\text { environment (e.g. government, competitors, suppliers, and } \\
\text { customers). }\end{array}$ \\
\hline & OVR2 & $\begin{array}{l}\text { Rate your level of knowledge of the goals and objectives of the } \\
\text { organization as whole. }\end{array}$ \\
\hline & OVR3 & $\begin{array}{l}\text { Rate your level of knowledge of the core capabilities of the } \\
\text { organization. }\end{array}$ \\
\hline & OVR4 & $\begin{array}{l}\text { Rate your level of knowledge of the key factors that must go right } \\
\text { for the organization to succeed. }\end{array}$ \\
\hline \multirow[t]{4}{*}{$\begin{array}{l}\text { Organizational } \\
\text { units }\end{array}$} & UNT1 & $\begin{array}{l}\text { Rate your level of knowledge of the main challenges that different } \\
\text { divisions in the organization face in achieving their objectives. }\end{array}$ \\
\hline & UNT2 & $\begin{array}{l}\text { Rate your level of knowledge of the language (e.g. key concepts, } \\
\text { jargon, ect.) of the different divisions in the organization. }\end{array}$ \\
\hline & UNT3 & $\begin{array}{l}\text { How well do you understand the work processes of the different } \\
\text { divisions in your organization? }\end{array}$ \\
\hline & UNT4 & $\begin{array}{l}\text { Rate your level of knowledge of the connections and } \\
\text { interdependencies between the various divisions in the } \\
\text { organization. }\end{array}$ \\
\hline \multirow[t]{4}{*}{$\begin{array}{l}\text { Organizational } \\
\text { responsibility }\end{array}$} & RES1 & $\begin{array}{l}\text { To what extend do you take actions to stay informed about } \\
\text { business development not directly related to IT? }\end{array}$ \\
\hline & RES2 & $\begin{array}{l}\text { How much do you participate in business activities that are not } \\
\text { directly related to IT? }\end{array}$ \\
\hline & RES3 & $\begin{array}{l}\text { To what extent are you concerned by the overall performance of } \\
\text { your business organization? }\end{array}$ \\
\hline & RES4 & $\begin{array}{l}\text { To what extent does your work have an impact on the } \\
\text { performance of the organization? }\end{array}$ \\
\hline \multirow[t]{5}{*}{$\begin{array}{l}\text { IT-business } \\
\text { integration }\end{array}$} & ITG1 & $\begin{array}{l}\text { How experienced are you at recognizing potential ways to exploit } \\
\text { new business opportunities using IT? }\end{array}$ \\
\hline & ITG2 & $\begin{array}{l}\text { How experienced are you at analyzing business problems in order } \\
\text { to identify IT-based solutions (understanding situations, getting } \\
\text { the "big picture" identifying underlying root problems, etc.)? }\end{array}$ \\
\hline & ITG3 & $\begin{array}{l}\text { How experienced are you at evaluating the organizational impacts } \\
\text { of IT solutions? }\end{array}$ \\
\hline & ITG4 & $\begin{array}{l}\text { Rate your level of knowledge of the alignment between business } \\
\text { goals and information systems in the organization as a whole. }\end{array}$ \\
\hline & ITG5 & $\begin{array}{l}\text { Rate your level of knowledge of the way IT contributes to the } \\
\text { value of the organization. }\end{array}$ \\
\hline
\end{tabular}

Note: All items are measured on a 5-point Likert-type scale: very low (1), low (2), neutral (3), high (4), very high (5); * Reverse scale items. 
Table 3. Items for business competence regarding interpersonal and management knowledge (Adapted from Bassellier and Benbasat (2004))

\begin{tabular}{|c|c|c|}
\hline Dimension & $\begin{array}{l}\text { Variable } \\
\text { name }\end{array}$ & Question \\
\hline \multirow[t]{3}{*}{$\begin{array}{l}\text { Knowledge } \\
\text { networking }\end{array}$} & NET1 & $\begin{array}{l}\text { If you have a business question or problem that you cannot } \\
\text { solve alone, how confident are you about finding the right } \\
\text { person to contact in your organization? }\end{array}$ \\
\hline & NET2 & $\begin{array}{l}\text { If you have a business question or problem that you cannot } \\
\text { solve alone, how confident are you about finding the right } \\
\text { contacts outside your organization (consultants, vendors)? }\end{array}$ \\
\hline & NET3 & $\begin{array}{l}\text { If you have a business question or problem that you cannot } \\
\text { solve alone, how confident are you about finding other relevant } \\
\text { sources of business Information including Internet site, } \\
\text { magazines, trade journals, and conferences? }\end{array}$ \\
\hline \multirow[t]{3}{*}{$\begin{array}{l}\text { Interpersonal } \\
\text { communication }\end{array}$} & COM1 & $\begin{array}{l}\text { In general, how effective do you think you are at } \\
\text { communicating with people at different levels of the } \\
\text { organization (e.g., with your subordinates, peers, superiors)? }\end{array}$ \\
\hline & COM2 & How effective are you at working in a team environment? \\
\hline & COM3 & $\begin{array}{l}\text { How well can you communicate about IT matters in non- } \\
\text { technical language and within a business context to non-IT } \\
\text { specialists? }\end{array}$ \\
\hline \multirow[t]{4}{*}{ Leadership } & LEA1 & $\begin{array}{l}\text { In general, how effective do you think you are at managing } \\
\text { projects (planning, managing resources, evaluating, etc.)? }\end{array}$ \\
\hline & LEA2 & $\begin{array}{l}\text { In general, how effective do you think you are at acting } \\
\text { in a leadership role (e.g. establishing direction, directing } \\
\text { people, motivating and inspiring, etc.)? }\end{array}$ \\
\hline & LEA3 & $\begin{array}{l}\text { Rate your level of knowledge of the existing practices for } \\
\text { the management of change in the organization. }\end{array}$ \\
\hline & LEA4 & $\begin{array}{l}\text { Rate your level of knowledge of the risk management practices } \\
\text { that can be applied in the organization. }\end{array}$ \\
\hline
\end{tabular}

Note: All items are measured on a 5-point Likert-type scale: very low (1), low (2), neutral (3), high (4), very high (5); * Reverse scale items.

To measure the dependent variables related to job satisfaction we adopted the questionnaire that was used in previous studies (Vitell, Davis 1990). These variables are depicted in Table 4.

\subsection{Research questionnaire adaptation and testing}

We decided to adopt several changes to survey instruments. Basselier and Benbasat (2004) used 5 points on the Business Competency scale, while Vitell and Davis (1990) used 7 points on the Job Satisfaction scale.

The questionnaire was translated from English to Polish and adapted to cultural and business conditions in Poland. The adaptation included the method of competent judges, items discriminatory power, scales validity (CFA) and reliability (Cronbach's $\alpha$ ) analysis. 
Table 4. Items for job satisfaction (Adapted from Vitell and Davis (1990))

\begin{tabular}{|c|c|c|}
\hline Dimension & $\begin{array}{l}\text { Variable } \\
\text { name }\end{array}$ & Question \\
\hline \multirow{4}{*}{$\begin{array}{l}\text { Satisfaction } \\
\text { with pay }\end{array}$} & SPAY1 & My organization pays better than competitors. \\
\hline & SPAY2 & My pay is adequate, considering the responsibilities I have. \\
\hline & SPAY3 & I am underpaid for what I do. * \\
\hline & SPAY4 & My fringe benefits are generous. \\
\hline \multirow[t]{4}{*}{$\begin{array}{l}\text { Satisfaction } \\
\text { with promotion }\end{array}$} & SPRO1 & $\begin{array}{l}\text { I do not like the basis on which my organization promotes } \\
\text { people. * }\end{array}$ \\
\hline & SPRO2 & Promotions are infrequent in my organization.* \\
\hline & SPRO3 & If I do a good job, I am likely to get promoted. \\
\hline & SPRO4 & I am satisfied with my rate of advancements. \\
\hline \multirow{4}{*}{$\begin{array}{l}\text { Satisfaction } \\
\text { with } \\
\text { co-workers }\end{array}$} & SCOL1 & The people I work with do not give me enough support. * \\
\hline & SCOL2 & When I ask people to do things, the job gets done. \\
\hline & SCOL3 & I enjoy working with the people here. \\
\hline & SCOL4 & I work with responsible people. \\
\hline \multirow{4}{*}{$\begin{array}{l}\text { Satisfaction } \\
\text { with supervisor }\end{array}$} & SBOS1 & The manager I work for back me up. \\
\hline & SBOS2 & The managers I work for are "top notch". \\
\hline & SBOS3 & My superiors don't listen to me. * \\
\hline & SBOS4 & My management doesn't treat me fairly. ${ }^{*}$ \\
\hline \multirow{4}{*}{$\begin{array}{l}\text { Satisfaction } \\
\text { with work itself }\end{array}$} & SJOB1 & My job is interesting. \\
\hline & SJOB2 & I feel good about the amount of responsibility in my job. \\
\hline & SJOB3 & I would rather be doing another job. * \\
\hline & SJOB4 & I get little sense of accomplishment from doing my job. * \\
\hline
\end{tabular}

Note: All items are measured on a 5-point scale: strongly disagree (1), disagree (2), neutral (3), agree (4), strongly agree (5); * Reverse scale items.

For all dimensions in both questionnaires standardized Cronbach's alpha coefficients were greater than 0.8 . To check for the quality of translation, the questionnaires were then translated back in English by a different translator. This version was very similar to the original one.

Our questionnaire's adaptations were made to the content, format, and response options of some part of the questions (Harkness et al. 2010). The goal of the adaptations was to better fit the questionnaires to the needs of the Polish population, language, culture, social structures and business environment. To assess the discriminant validity of the construct, we examined with the Average Variance Extracted (AVE) method, whether the amount of variance explained by the construct in relation to the amount of variance due to the measurement error is significant (Fornell, Larcker 1981; MacKenzie et al. 2011). The AVE results for Business Competence and Job Satisfaction constructs were 
statistically significant and respectively equal to: AVE (BC) $>0.78$ and AVE (JS) $>0.68$, which are quite acceptable results for both adapted questionnaires.

Validity manifested by content, criterion, and construct validity is related to the extent to which an instrument measures what it is intended to measure (Cronbach, Meehl 1955). Constructs (dimensions, for example Job Satisfaction or Business Competency) validity is crucial to the overall observed validity of the test and we verified it by using the methods of the Confirmatory Factor Analysis (CFA) as described by Thompson (2004). The results concerning validity for both adapted questionnaires were positive; the tracking errors data indicated by the RMSEA statistics for Job Satisfaction was 0.04 and 0.03 for Business Competency. As an external criterion for evaluating the validity, we have chosen the average rates (on a scale of 1 to 5) of compliance questionnaires given by competent judges, which in the case of both questionnaires were fairly high. The results of Job Satisfaction included the mean of $m=4.3$, the Kendall's coefficient of concordance $\mathrm{W}=0.8$, and for the Business Competency results were equal to $\mathrm{m}=$ 4.1 and $\mathrm{W}=0.7$, respectively.

Reliability (ability of an instrument to measure consistently) was estimated by Cronbach's alpha, with satisfying results. The Cronbach's alpha and average correlation coefficient for Business Competency Scale were equal to alpha $=0.94$ and $r=0.7$ and for the Job Satisfaction Scale the results were: alpha $=0.90$ and $r=0.6$, respectively.

\subsection{Participants and data collection}

In February 2012, a questionnaire was posted on the website of the College of Management "Edukacja" in Wroclaw, Poland. Contact information of potential participants was retrieved from two databases: one compiled by the Centre for Scientific Research of College of Management "Edukacja" and second by the NOT-Federation of Engineering in Wrocław. These databases include several thousand representative addresses of IT specialists from across the country.

In the e-mail invitation sent by the first author to potential respondents, the research value of this survey was explained along with the previous work that was related to the topic of job satisfaction. No incentives were offered to the participants. From February 2012 to February 2013, 391 participants completed the online questionnaire, as depicted in Table 5.

The representativeness of the IT professionals sample was confirmed by control variables, such as the respondents' age, gender, income level, and the size of the company they work for. For example, in regard to the size of company, about 77 percent of respondents participating in our survey were employed in small and medium-sized companies, which is comparable to the national employment figures and published by the Polish Agency for Enterprise Development (2010). 
Table 5. Sample characteristics $(\mathrm{N}=391)$

\begin{tabular}{|c|c|c|}
\hline Variables and categories & Quantity & Percent \\
\hline \multicolumn{3}{|c|}{ Age in years } \\
\hline Less than 20 & 19 & 5 \\
\hline $20-29$ & 165 & 42 \\
\hline $30-39$ & 145 & 37 \\
\hline $40-49$ & 43 & 11 \\
\hline $50-69$ & 19 & 5 \\
\hline Total & 391 & 100 \\
\hline \multicolumn{3}{|l|}{ Gender } \\
\hline Male & 239 & 61 \\
\hline Female & 152 & 39 \\
\hline Total & 391 & 100 \\
\hline \multicolumn{3}{|l|}{ Firm size } \\
\hline Micro - up to 9 people & 71 & 17 \\
\hline Small - from 10 to 49 people & 77 & 20 \\
\hline Medium - from 50 to 250 people & 155 & 40 \\
\hline Large - from 250 people & 88 & 23 \\
\hline Total & 391 & 100 \\
\hline \multicolumn{3}{|c|}{ Level of salary } \\
\hline Much lower than average & 24 & 6 \\
\hline Lower than average & 61 & 16 \\
\hline Average level & 142 & 36 \\
\hline Above average & 129 & 33 \\
\hline Much above average & 35 & 9 \\
\hline Total & 391 & 100 \\
\hline
\end{tabular}

\subsection{Statistical methods}

In our analysis, for each of the variables used in our research, common measures of central tendency and of dispersion, such as the arithmetic mean (the simple average, in this paper denoted as $m$ ), the median (Me), the standard deviation (s), skewness (a3) and kurtosis $(a 4)$ were calculated. To assess the strength of relation between the variables describing business competency and job satisfaction, and so to test our hypotheses, the Pearson product-moment correlation coefficient (denoted as $r$ ) was applied.

Furthermore, for the verification of the research hypotheses and for the purpose of generalizing the conclusions coming from this study on the general population, a $95 \%$ confidence interval (significance level of 0.05 ) for the mean was constructed. 


\section{Results}

The descriptive statistics is depicted in Table 6 and the results of the correlation analysis are summarized in Table 7.

As it could be seen from Table 7, all aspects of job satisfaction are related to competency. The strength of the relation varies across items, however. Business competence of IT professionals in our sample seems to have a significant effect on their satisfaction with co-workers, supervisors, and work itself. In contrast, only a quarter $(25 \%)$ of the respondents feel that their competency has an effect on their pay. For example, our analysis results show that influence of such dimensions like Interpersonal and Management Knowledge (IMK) and satisfaction with pay (SPAY) on Job Satisfaction (JS) is positive and statistically significant but not strong. Moreover, knowledge about the business integration seems to have only a marginal effect on job satisfaction in Polish conditions and the correlation may explain only maximum of $36 \%$ variation of job satisfaction. The main results of our analysis are summarized in Figure 2.

Table 6. Descriptive statistics $(\mathrm{N}=391)$

\begin{tabular}{|c|c|c|c|c|c|c|c|c|}
\hline Variable codes & Long variable labels & $m$ & $l l$ & $r l$ & Me & $s$ & $a 3$ & $a 4$ \\
\hline M8_age: & Age & 32.8 & 31.9 & 33.7 & 31 & 9.2 & 1 & 1 \\
\hline OVR & Organizational overview & 3.6 & 3.5 & 3.7 & 3.8 & 0.9 & -0.2 & -0.6 \\
\hline UNT & Organizational units & 3.6 & 3.5 & 3.7 & 3.8 & 0.9 & -0.3 & -0.6 \\
\hline RES & Organizational responsibility & 3.4 & 3.3 & 3.4 & 3.3 & 0.9 & 0 & -0.6 \\
\hline ITG & IT-business integration & 3.3 & 3.2 & 3.4 & 3 & 1 & 0.1 & -0.5 \\
\hline OSBK & $\begin{array}{l}\text { Organization specific } \\
\text { business knowledge }\end{array}$ & 3.5 & 3.4 & 3.5 & 3.4 & 0.8 & 0.3 & -0.7 \\
\hline NET & Knowledge networking & 3.6 & 3.5 & 3.7 & 3.7 & 1 & -0.3 & -0.7 \\
\hline $\mathrm{COM}$ & Interpersonal communication & 3.7 & 3.6 & 3.8 & 4 & 1 & -0.6 & -0.5 \\
\hline LEA & Leadership & 3.5 & 3.4 & 3.6 & 3.5 & 0.9 & -0.1 & -0.8 \\
\hline IMK & $\begin{array}{l}\text { Interpersonal and } \\
\text { management knowledge }\end{array}$ & 3.6 & 3.5 & 3.7 & 3.7 & 0.9 & -0.1 & -0.9 \\
\hline $\mathrm{BC}$ & Business competence & 3.5 & 3.4 & 3.6 & 3.5 & 0.8 & 0.2 & -0.8 \\
\hline SPAY & Satisfaction with pay & 2.7 & 2.6 & 2.8 & 2.5 & 0.9 & 0.2 & -0.6 \\
\hline SPRO & Satisfaction with promotions & 2.7 & 2.6 & 2.8 & 2.8 & 0.9 & 0.4 & -0.2 \\
\hline SCOL & Satisfaction with co-worker & 3.3 & 3.2 & 3.4 & 3.5 & 1 & -0.1 & -1.1 \\
\hline SBOS & Satisfaction with supervisors & 3.3 & 3.2 & 3.4 & 3 & 1.1 & 0.1 & -1.2 \\
\hline SJOB & Satisfaction with work itself & 3.4 & 3.3 & 3.5 & 3.5 & 1.2 & -0.1 & -1.2 \\
\hline JS & Global job satisfaction & 3.1 & 3 & 3.2 & 3.1 & 0.9 & 0.2 & -1 \\
\hline
\end{tabular}

Designations: $m$ - mean; $l l-95 \%$ confidential interval left limit; $r l-95 \%$ confidential interval right limit; $M e$ - median; $s$ - standard deviation; $a 3$ - skewness; $a 4$ - kurtosis. 
Table 7. Pearson's linear correlation coefficient matrix

\begin{tabular}{|c|c|c|c|c|c|c|}
\hline Variable & $\begin{array}{c}\text { SPAY: } \\
\text { satisfaction } \\
\text { with pay }\end{array}$ & $\begin{array}{c}\text { SPRO: } \\
\text { satisfaction } \\
\text { with } \\
\text { promotion }\end{array}$ & $\begin{array}{c}\text { SCOL: } \\
\text { satisfaction } \\
\text { with } \\
\text { co-workers }\end{array}$ & $\begin{array}{c}\text { SBOS: } \\
\text { satisfaction } \\
\text { with } \\
\text { supervision }\end{array}$ & $\begin{array}{c}\text { SJOB: } \\
\text { satisfaction } \\
\text { with work } \\
\text { itself }\end{array}$ & $\begin{array}{l}\text { JS: global } \\
\text { job } \\
\text { satisfaction }\end{array}$ \\
\hline $\begin{array}{l}\text { OVR: } \\
\text { organizational } \\
\text { overview }\end{array}$ & 0.5 & 0.5 & 0.6 & 0.6 & 0.6 & 0.7 \\
\hline $\begin{array}{l}\text { UNT: } \\
\text { organizational } \\
\text { units }\end{array}$ & 0.4 & 0.4 & 0.6 & 0.6 & 0.6 & 0.6 \\
\hline $\begin{array}{l}\text { RES: } \\
\text { organizational } \\
\text { responsibility }\end{array}$ & 0.5 & 0.5 & 0.6 & 0.6 & 0.6 & 0.7 \\
\hline $\begin{array}{l}\text { ITG: IT-business } \\
\text { integration }\end{array}$ & 0.5 & 0.4 & 0.5 & 0.5 & 0.5 & 0.6 \\
\hline $\begin{array}{l}\text { OSBK: = } \\
\text { OVR + UNT + } \\
\text { RES + ITG: } \\
\text { organization } \\
\text { specific business } \\
\text { knowledge }\end{array}$ & 0.5 & 0.5 & 0.6 & 0.6 & 0.7 & 0.7 \\
\hline $\begin{array}{l}\text { NET: knowledge } \\
\text { networking }\end{array}$ & 0.4 & 0.4 & 0.6 & 0.6 & 0.6 & 0.6 \\
\hline $\begin{array}{l}\text { COM: } \\
\text { interpersonal } \\
\text { communication }\end{array}$ & 0.4 & 0.4 & 0.7 & 0.6 & 0.6 & 0.7 \\
\hline LEA: leadership & 0.5 & 0.4 & 0.6 & 0.6 & 0.6 & 0.7 \\
\hline $\begin{array}{l}\text { IMK: = NET + } \\
\text { COM + LEA: } \\
\text { interpersonal } \\
\text { and } \\
\text { management } \\
\text { knowledge }\end{array}$ & 0.5 & 0.5 & 0.7 & 0.7 & 0.7 & 0.7 \\
\hline $\begin{array}{l}\text { BC: }=\text { OSBK + } \\
\text { IMK: business } \\
\text { competence }\end{array}$ & 0.5 & 0.5 & 0.7 & 0.7 & 0.7 & 0.8 \\
\hline
\end{tabular}

In summary, business competence of IT professionals in transition economies has a significant effect on their job satisfaction as summarized in Table 8. 


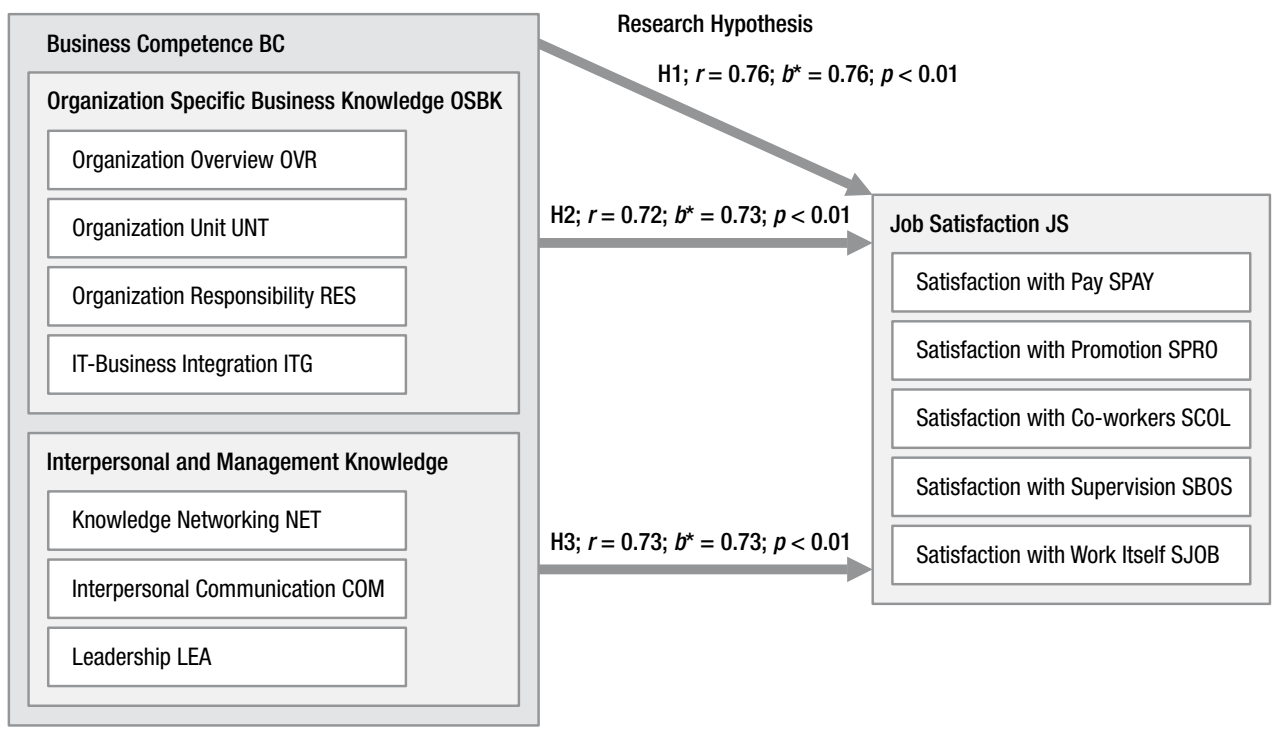

Fig. 2. Business competence and its effect on job satisfaction

Table 8. Overview of results

\begin{tabular}{ccl}
\hline Hypothesis & Supported & \multicolumn{1}{c}{ Comments } \\
\hline 1 & Yes & $\begin{array}{l}\text { Business competence of IT professionals has a significant } \\
\text { effect on their job satisfaction. }\end{array}$ \\
\hline 2 & Yes & $\begin{array}{l}\text { Organization specific business knowledge of IT professionals } \\
\text { has a significant effect on their job satisfaction. }\end{array}$ \\
\hline 3 & Yes & $\begin{array}{l}\text { Interpersonal and management knowledge of IT professionals } \\
\text { has a significant effect on their job satisfaction. }\end{array}$ \\
\hline
\end{tabular}

\section{Discussion}

There are two important findings in our study. First, business competency seems to be related to the overall job satisfaction of IT professionals in transition economies. However, many IT professionals feel that their compensation level and promotion opportunities are inadequate for the competency they possess. A possible explanation could be seen in the existing compensation structures in many Polish companies. Frequently, in Polish companies it may be difficult to offer competitive compensations for a small group of talented workers. Moreover, a large number of newly-graduated IT professional seeking jobs, may depress the salary level for the whole group. This imbalance between a large number of IT professionals seeking jobs and relatively small number of job openings is typical for the job markets of many transition economies. In those job markets, relative high demand enjoy professions such as maintenance personal, cleaners, janitors, sales force, security personnel and construction workers, while job offers for university graduates are rather rare (Kowal et al. 2010). In essence, the situation in the job markets in transition economies mirrors their phases of the transition process. Although the transition economies are able to attract foreign investors 
yet, the difficulty in attracting and retaining headquarters of global players persists; while, knowledge and technology is imported from developed countries than created (Roztocki 2012). Furthermore, as many IT outsourcing initiatives have commodity character and seek cost advantage rather than look for special skills, they could often be conducted with the help of newly-graduated IT professionals. Consequently, the demand for extremely qualified, experienced knowledge workers is flat and, as a result, many of the requests for radical salary increases and promotions from these workers could be simply turned down.

Second, possessing knowledge of IT-business integration by IT professionals working in Polish organizations seem to have only a marginal effect on their job satisfaction. According to research reports from developed, matured economies, IT professionals should be encouraged to act as problem solvers for business-related issues (Bassellier, Benbasat 2004). Thus, in essence, IT-business integration requires from IT professionals an ability to recognize ways in which IT could be used to increase business performance. It requires solid business knowledge combined with a high level of abstraction and creativity that allows connecting various IT solutions with existing business problems. One explanation of this could be seen in the education of Polish IT professionals that emphasize technical skills. It is also quite possible that middle management in many Polish companies does not value acquiring additional business knowledge by their employees and rather discourages business thinking. To this extent, a more recent study reports that 67 percent of Polish managers believe that there is no need for continuous, professional training (Kowal 2011). In essence, this middle managers' resistance to continuous training and education, which is essential for competitiveness in this global knowledge economy, could be seen as a relic from the communist past. Many decisionmakers currently holding managerial positions in Poland were educated and started their careers in a centrally planned economic system. In this old, communist system, there was no need for business thinking and initiative by young employees were suppressed, and individuals showing signs of excelling within a group were seen as destructive for socialist group harmony (Lange 2009; Longenecker, Popovski 1994).

\section{Conclusions, limitations and future research}

To conclude, we believe that our research presented in this paper makes a substantial contribution to the existing knowledge. It provides practical implications that governments in transition economies should pay more attention to development of human capital. For example, transition economies should encourage more competency related education and training by providing tax incentives for companies that participate in such programs. Our research is subject to several limitations. First, our survey is conducted in only one country. Conducting a survey in several similar countries would allow a comparison and generalization of the findings to other transition economies. Second, business competencies are self-reported by the participants as a subjective selfevaluation. A test that would verify the business competencies of each participant could produce a more realistic picture. Third, in our analysis we did not specifically account for differences in the demographic profile of the participants such as gender and age. This kind of analysis could produce additional interesting results. 
To conclude, we hope that our research presented in this paper will inspire other researchers to conduct their own research on this interesting topic.

\section{Acknowledgements}

An earlier version of this paper was presented at the Eighteen Americas Conference on Information Systems (AMCIS 2012) hosted in Seattle, Washington August 9-11, 2012. We would like to thank the conference participants for their valuable comments and suggestions.

\section{Funding}

This work was supported by the University of Wrocław [grant number 2019/S/IPS/2012].

\section{References}

Bassellier, G.; Benbasat, I. 2004. Business competence of information technology professionals: conceptual development and influence on IT-business partnerships, MIS Quarterly 28(4): 673-694.

Bassellier, G.; Horner Reich, B.; Benbasat, I. 2001. Information technology competence of business managers: a definition and research model, Journal of Management Information Systems 17(4): 159-182.

Carraher, S. M.; Carraher, S. C. 2006. Human resource issue among SMES in Eastern Europe: a 30 month study in Belarus, Poland, and Ukraine, International Journal of Entrepreneurship 10: $97-108$.

Cronbach, L. J.; Meehl, P. E. 1955. Construct validity in psychological tests, Psychological Bulletin 52(4): 281-302. http://dx.doi.org/10.1037/h0040957

Díaz-Fernández, M.; López-Cabrales, A.; Valle-Cabrera, R. 2014. A contingent approach to the role of human capital and competencies on firm strategy, BRQ Business Research Quarterly 17(3): 205-222. http://dx.doi.org/10.1016/j.brq.2014.01.002

Eyupoglu, S. Z.; Saner, T. 2009. Job satisfaction: does rank make a difference?, African Journal of Business Management 3(10): 609-615.

Fargher, S.; Kesting, S.; Lange, T.; Pacheco, G. 2008. Cultural heritage and job satisfaction in Eastern and Western Europe, International Journal of Manpower 29(7): 630-650.

http://dx.doi.org/10.1108/01437720810908938

Fornell, C.; Larcker, D. F. 1981. Evaluating structural equation models with unobservable variables and measurement error, Journal of Marketing Research 18(1): 39-50.

http://dx.doi.org/10.2307/3151312

Harkness, J. A.; Villar, A.; Edwards, B. 2010. Translation, adaptation, and design, in J. A. Harkness, M. Braun, B. Edwards, T. P. Johnson, L. Lyberg, P. P. Mohler, B.-E. Pennell, T. W. Smith (Eds.). Survey methods in multinational, multiregional, and multicultural contexts. Hoboken, NJ: Wiley, 117-140. http://dx.doi.org/10.1002/9780470609927.ch7

Koh, C. H.; Boo, E. F. H. Y. 2001. The link between organizational ethics and job satisfaction: a study of managers in Singapore, Journal of Business Ethics 29(4): 309-324.

http://dx.doi.org/10.1023/A:1010741519818

Kowal, J. 2011. Perspectives and directions for professional development in the Lower Silesian Voivodeship compared to Poland and the European Union, Proceedings of the 7th European Conference on Management, Leadership and Governance (ECMLG 2011), 6-7 October 2011, SKEMA Business School, Sophia-Antipolis, France, 206-215. 
Kowal, J.; Kwiatkowska, A.; Patro, I. 2010. The Prospects of graduates' career development in Poland: the example of a competence survey in the Lower Silesian region 2006-2010, in Proceedings of the 6th European Conference on Management Leadership and Governance (ECMLG 2010), 28-29 October 2010, College of Management Edukacja and the Professional Development Center Edukacja, Wroclaw, Poland.

Kowal, J.; Roztocki, N. 2013. Information and communication technology management for global competitiveness and economic growth in emerging economies, The Electronic Journal of Information Systems in Developing Countries 57 [online], [cited 1 April 2014]. Available from Internet: https://www.ejisdc.org/ojs2/index.php/ejisdc/article/view/1159.

Kowal, J.; Roztocki, N. 2015. Do organizational ethics improve IT job satisfaction in the Visegrád group countries? Insights from Poland, Journal of Global Information Technology Management 18(2): 127-145. http://dx.doi.org/10.1080/1097198X.2015.1052687

Kozminski, A. K. 2008. Anatomy of systemic change: Polish management in transition, Communist and Post-Communist Studies 41(3): 263-280.

http://dx.doi.org/10.1016/j.postcomstud.2008.06.006

Lange, T. 2009. Attitudes, attributes and institutions: determining job satisfaction in Central and Eastern Europe, Employee Relation 31(1): 81-97. http://dx.doi.org/10.1108/01425450910916832

Linz, S. J. 2003. Job satisfaction among Russian workers, International Journal of Manpower 24(6): 625-652. http://dx.doi.org/10.1108/01437720310496139

Longenecker, C. O.; Popovski, S. 1994. Managerial trials of privatization: retooling Russian managers, Business Horizons 37(6): 35-43. http://dx.doi.org/10.1016/S0007-6813(05)80243-5

MacKenzie, S. B.; Podsakoff, P. M.; Podsakoff, N. P. 2011. Construct measurement and validation procedures in MIS and behavioral research: integrating new and existing techniques, MIS Quarterly 35(2): 293-334.

Parts, V.; Teichmann, M.; Ruutmann, T. 2013. Would enginners need non-technical skills or nontechnical competences or both?, International Journal of Engineering Pedagogy 3(2): 14-19.

Piotrowicz, W. 2015. Information technology and systems in the Visegrád group of countries (Czech Republic, Hungary, Poland, and Slovakia): a literature review. Journal of Global Information Technology Management 18(2): 77-93. http://dx.doi.org/10.1080/1097198X.2015.1052684

Polish Agency for Enterprise Development. 2010. Report on the conditions of small and mediumsized enterprise sector in Poland in the years 2008-2009. Warsaw.

Roztocki, N. 2012. Stock market reaction to information technology investments in the USA and Poland: a comparative event study, in Proceedings of the 45th Hawaii International Conference on System Sciences (HICSS-2012), 4-7 January 2012, Maui, Hawaii, USA.

http://dx.doi.org/10.1109/HICSS.2012.548

Roztocki, N.; Weistroffer, H. R. 2008. Information technology in transition economies, Journal of Global Information Technology Management 11(4): 2-9.

http://dx.doi.org/10.1080/1097198X.2008.10856476

Roztocki, N.; Weistroffer, H. R. 2009. Research trends in information and communications technology in developing, emerging and transition economies, Roczniki Kolegium Analiz Ekonomicznych (Annals of the Collegium of Economic Analysis) 20: 113-127 [online], [cited 1 April 2014]. SSRN. Available from Internet: http://ssrn.com/abstract=1577270.

Roztocki, N.; Weistroffer, H. R. 2011a. From the special issue editors: information technology in transition economies, Information Systems Management 28(3): 188-191.

Roztocki, N.; Weistroffer, H. R. 2011b. Information technology success factors and models in developing and emerging economies, Information Technology for Development 17(3): 163-167. http://dx.doi.org/10.1080/02681102.2011.568220

Roztocki, N. Weistroffer, H. R. 2015. Information and communication technology in transition economies: an assessment of research trends, Information Technology for Development 21(3): 330-364. http://dx.doi.org/10.1080/02681102.2014.891498 
Sakowski, P. 2012. Job satisfaction of occupational medicine nurses in Poland, International Journal of Occupational Medicine and Environmental Health 25(1): 51-58.

http://dx.doi.org/10.2478/s13382-012-0006-x

Soja, P. 2008. An interview with Wojciech Wierzba: President, Digitland, Krakow, Poland, Journal of Global Information Technology Management 11(4): 76-80.

http://dx.doi.org/10.1080/1097198X.2008.10856480

Soja, P.; Paliwoda-Pekosz, G. 2013. Impediments to enterprise system implementation over the system lifecycle: contrasting transition and developed economies, Electronic Journal of Information Systems in Developing Countries 57 [online], [cited 1 April 2014]. Available from Internet: https://www.ejisdc.org/ojs2/index.php/ejisdc/article/view/1157.

Spector, P. E. 1985. Measurement of human service staff satisfaction: development of the job satisfaction survey, American Journal of Community Psychology 13(6): 693-713.

http://dx.doi.org/10.1007/BF00929796

Thompson, B. 2004. Exploratory and confirmatory factor analysis: understanding concepts and applications. American Psychological Association, Washington, DC.

http://dx.doi.org/10.1037/10694-000

Todd, P. A.; McKeen, J. D.; Gallupe, R. B. 1995. The evolution of IS job skills: a content analysis of IS job advertisements from 1970 to 1990, MIS Quarterly 19(1): 1-27.

http://dx.doi.org/10.2307/249709

Ubius, U.; Alas, R.; Elenurm, T. 2013. Impact of innovation climate on individual and organisational level factors in Asia and Europe, Journal of Business Economics and Management 14(1): 1-21. http://dx.doi.org/10.3846/16111699.2011.642081

Vila, L. E.; Pérez, P. J.; Coll-Serrano, V. 2014. Innovation at the workplace: do professional competencies matter?, Journal of Business Research 67(5): 752-757.

http://dx.doi.org/10.1016/j.jbusres.2013.11.039

Vitell, S. J.; Davis, D. L. 1990. The relationship between ethics and job satisfaction: an empirical investigation, Journal of Business Ethics 9(6): 489-494. http://dx.doi.org/10.1007/BF00382842

Woodruffe, C. 1993. What is meant by a competency?, Leadership \& Organization Development Journal 14(1): 29-36. http://dx.doi.org/10.1108/eb053651

Jolanta KOWAL (Doctor of Economic Sciences) is Adjunct in the Institute of Psychology at the University of Wrocław, Poland and Associate Professor at the College of Management "Edukacja", Wrocław, Poland. Her research focuses on methodology, management, competences, job satisfaction, business ethics, corporate social responsibility, and multicultural influences of psychoanalysis. She published her work in the Journal of Global Information Technology Management and the Electronic Journal of Information Systems in Developing Countries, among many others. Jolanta has given lectures concerning her research in Bulgaria, Cyprus, Czech Republic, France, Great Britain and Slovakia. She has organized several international conferences in Poland and abroad. Jolanta is also a member of editorial boards of two scientific journals: the Polish Journal of Applied Psychology and the journal Gospodarka Rynek Edukacja.

Narcyz ROZTOCKI (PhD) is Professor of Management Information Systems at the State University of New York at New Paltz, USA and Professor at the Kozminski University, Warsaw, Poland. His research interests include IS/IT investment evaluation, IS/IT productivity, IS/IT investments in transition/emerging economies, technology project management, and e-commerce. He has been published in numerous journals including the European Journal of Information Systems, the Journal of Strategic Information System, the Journal of Computer Information Systems, the Electronic Journal of Information Systems in Developing Countries, the Journal of Global Information Technology Management, , and in proceedings of AMCIS, DSI, ECIS, ECITE, and HICSS, among many others. 